\title{
The Effects of Pre-Treatment and Post- Treatment of Thymol against tert-Butyl Hydroperoxide (t-BHP) Cytotoxicity in MCF-7 Cell Line and Fibroblast Derived Foreskin
}

\author{
Afsaneh Dashtaki ${ }^{1,3}$, Soleiman Mahjoub*2,3, \\ Ebrahim Zabihi ${ }^{2}$, Roghayeh Pourbagher ${ }^{2}$
}

\begin{abstract}
Background: Some recent studies have reported anti-tumor activity for Thymol, but the findings are inconsistent. This study aimed to investigate and compare Thymol's effects on MCF-7 cancer cells and fibroblasts while treated with tert-Butyl hydroperoxide (t-BHP).

Methods: In the pre-treatment, MCF-7 and fibroblast cells were treated with various Thymol concentrations and incubated for $24 \mathrm{~h}$. Then, t-BHP was added to a final concentration of $50 \mu \mathrm{M}$, and the cells were incubated for one $\mathrm{h}$. In the post-treatment, cells were incubated first with $50 \mu \mathrm{M} \mathrm{t}$-BHP for one $\mathrm{h}$ and then treated with Thymol. Cell viability was tested by 3-(4,5-Dimethylthiazol-2-yl)-2,5-diphenyltetrazolium bromide (MTT) assay. Thymol's antioxidant capacity was measured by DPPH and FRAP assays, and lipid peroxidation levels were determined by the TBARS method.

Results: The thymol effects were dose-dependent, and despite their antioxidant properties, at concentrations of $100 \mu \mathrm{g} / \mathrm{ml}$ or more, increased t-BHP toxicity and reduced cancer cell viability. MTT assay result showed that pre-treatment and post-treatment with Thymol for 24 hours effectively reduced MCF-7 and fibroblast cell viability compared with the untreated control group. Both pre- and post-treatment of Thymol, normal fibroblast cell viability was significantly greater than that of the MCF-7 cells.

Conclusions: Our finding showed that Thymol appears to be toxic to MCF-7 cells at lower concentrations than fibroblasts after 24 hours of incubation. Pre-treatment with Thymol neutralized the oxidative effect of t-BHP in fibroblasts but was toxic for MCF-7 cells.
\end{abstract}

Keywords: Breast Cancer, MCF-7 Cells, Oxidative Stress, tert-Butyl Hydroperoxide, Thymol.

\section{Introduction}

Breast cancer is the most frequently occurring malignancy among females worldwide, with about 2.1 million new cases in 2018 (1). A combination of environmental and genetic factors plays a significant role in breast cancer (2). These risk factors may exert their effects through oxidative stress generation(3). Oxidative stress occurs due to an imbalance between the overproduction of reactive oxygen species (ROS) in the body and their removal by antioxidant defense systems (4). Under stress oxidative, normal cellular processes are impaired by ROS, including cell metabolism pathways, signaling pathways regulating gene expression, cell proliferation, differentiation, and apoptosis (3). During carcinogenesis, stress oxidative in cancer cells causes oxidative damage to the structure of lipids, proteins, and DNA, which play an essential role in the initiation and progression of breast 
cancer $(5,6)$. For controlling the overproduction of ROS, the cells are protected against oxidative stress by non-enzymatic antioxidants (reduced glutathione, vitamins $\mathrm{A}$, vitamin $\mathrm{E}$, vitamin $\mathrm{C}$, flavonoids, and metabolites of polyphenols) and various antioxidant enzymes (catalase, glutathione peroxidase, superoxide dismutase) (5).

Numerous epidemiological and experimental studies have demonstrated that natural phenolic products with antioxidant activity are associated with reducing the risk of various tumors, including breast cancer (7). Among many natural phenolic compounds, Thymol (2-isopropyl-5-methyl phenol) is a dietary monoterpene phenol which found in the essential oils of various plant sources such as thyme (Lamiaceae), oregano, and other plant species (8). Some of thymol biological activities such as antioxidant, free radical scavenging, anti-microbial, anti-fungal, antiinflammatory, and immunomodulatory effects have been studied (9-11). It has also been reported that Thymol exerts anticancer properties in different human cancer cell lines depending on the cell types and their concentration (9). Thymol was shown to protect against ROS-induced cytotoxicity and DNA damage in cancer cell lines depending on its concentration (12). Thymol's central anticancer mechanisms include the induction of apoptosis and inhibition of growth, angiogenesis, and migration of cancer cells (13-15).

t-BHP is an organic hydroperoxide that is used as a toxic and acute oxidant to study oxidative stress-mediated cellular damage (16). A previous in vitro study reported that Thymol could protect Chang liver cells against t-BHP-induced-oxidative damage through their ability to prevent liver cell death (16).

Given the contradictory results in studies and lack of study on the effect of high thymol concentrations on MCF-7 cells, we investigated the effect of thymol pre- and post-treatment on tBHP toxicity in MCF-7 and fibroblast cells.

\section{Materials and methods}

Preparation of CellsMCF-7 and foreskin fibroblast cells were used in this study. The cells were grown in 24- and 96-well plates. After reaching the desired confluency, cells were treated with Thymol and t-BHP.

\section{Treatment of cells with thymol and $t-B H P$}

MCF-7 and fibroblast cells were seeded at $10 \times 10^{3}$ and $12 \times 10^{3}$ cells per well, respectively, and incubated for $24 \mathrm{~h}$ at $37^{\circ} \mathrm{C}$. When the confluency reached $80 \%$, in the pre-treatment group, cells were first treated with $0,50,100,200,400$, or 800 $\mu \mathrm{g} / \mathrm{ml}$ of Thymol for $24 \mathrm{~h}$; then with 0 or $50 \mu \mathrm{M}$ $\mathrm{t}$-BHP for one $\mathrm{h}$. In the post-treatment group, cells were first incubated with $50 \mu \mathrm{M}$ t-BHP for one $\mathrm{h}$, then treated with Thymol as above.

The control groups received neither Thymol nor t-BHP. After 24 hours, the culture medium was collected for DPPH, ferric reducing antioxidant power (FRAP), and thiobarbituric acid reactive substances (TBARS) tests and the cells were used for 3-(4,5-Dimethylthiazol-2-yl)2,5-diphenyltetrazolium bromide (MTT) assays. All assays were performed in triplicate.

\section{Cytotoxicity and percentage of viability by MTT assay}

After incubations, the cell supernatants were removed, $50 \mu \mathrm{l}$ of MTT solution $(5 \mathrm{mg} / \mathrm{ml}$ in PBS) were added to each well, and plates were placed in a $\mathrm{CO}_{2}$ incubator at $37^{\circ} \mathrm{C}$ for three $\mathrm{h}$. After that, the supernatants were removed, and the DMSO solvent solubilized water-insoluble formazan crystals before the colorimetric process. Finally, the samples' optical absorption was read at $570 \mathrm{~nm}$ on an RT2100 model ELISA reader (Poway Medical Lab Equipment Co. Ltd., China) (17).

\section{Measurement of oxidative stress parameters DPPH method}

The specimens' free-radical scavenging activity was measured using the DPPH assay, which is commonly known as an antioxidant assay. The method is based on the ability to stabilize 2, 2diphenyl-1-picrylhydrazyl free radicals in reaction with hydrogen donors. In this method, $25 \mu \mathrm{l}$ of the sample was added to $975 \mu \mathrm{l}$ of DPPH at a concentration of $4 \times 10^{-5} \mu \mathrm{M}$. After $30 \mathrm{~min}$, the DPPH solution's adsorption was measured on a UNICO UV/VIS 2100 spectrophotometer at 517 nm. Data were analyzed using SPSS software version 22 and ANOVA test.

\section{FRAP method}

The total antioxidant capacity of the specimens was measured using the FRAP assay. $150 \mu \mathrm{L}$ of 
FRAP reagent (prepared by mixing $25 \mathrm{ml}$ of 300 $\mathrm{mM}$ acetate buffer $\mathrm{pH} 3.6,2.5 \mathrm{ml}$ of $10 \mathrm{mM}$ TPTZ solution, and $2.5 \mathrm{ml}$ of $20 \mathrm{mM} \mathrm{FeCl}_{3}$ solution in a 10:1:1 ratio) was added to all wells and plates were incubated for $5 \mathrm{~min}$ at $37{ }^{\circ} \mathrm{C}$. Subsequently, $20 \mu \mathrm{L}$ of standard and the treated cell supernatant samples were added to the wells and mixed, and the plates incubated for $15 \mathrm{~min}$ at $37{ }^{\circ} \mathrm{C}$. Color intensity at $593 \mathrm{~nm}$ was measured with the RT2100 ELISA reader. The obtained OD values were converted to concentrations using the standard curve.

\section{TBARS method}

Malondialdehyde (MDA), a biomarker of lipid peroxidation, was measured using the TBARS method. Under acidic conditions at $95{ }^{\circ} \mathrm{C}$, a malondialdehyde molecule reacts with two molecules of thiobarbituric acid (TBA) to form a pink complex with a maximum absorbance at $532 \mathrm{~nm})(18)$. In this method, $800 \mu \mathrm{l}$ of $\mathrm{HCl}-$ TBA-TCA solution was mixed with $200 \mu \mathrm{l}$ of the sample. The samples were placed in a boiling water bath for $45 \mathrm{~min}$, centrifuged at $1500 \mathrm{rpm}$ for $10 \mathrm{~min}$, and then the supernatant absorbance was read at $532 \mathrm{~nm}$.



t-BHP Concentration $(\mu \mathrm{M})$

\section{Statistical Analysis}

Data were analyzed using SPSS software version 22 and ANOVA test. Statistical significance between various experiments was determined by one-way analysis of variance (one-way ANOVA) followed by Tukey post-hoc analysis. Probability values (p-value) $* \mathrm{p}<0.05, * * \mathrm{p}<0.01$ and $* * * p<0.001$ were performed as a statistically significant difference.

\section{Results}

\section{Effect of $t$-BHP on MCF-7 and fibroblast cell survival}

The MTT assay determined the toxicity of various concentrations of $\mathrm{t}$-BHP $(0,12.5,25,50$, and $100 \mu \mathrm{M})$ on MCF-7 and fibroblast cell survival. After one h of t-BHP treatment, MCF-7 cell viability decreased from $57.19 \pm 10.9 \%$ to $18.9 \pm 9.1 \%$ in a dose-dependent manner $(\mathrm{p}<$ 0.01 and $p<0.001$ ) (Fig. 1A). The viability of fibroblast cells treated with 50 or $100 \mu \mathrm{M}$ of $\mathrm{t}$ BHP $(1 \mathrm{~h})$ was significantly less than that of the untreated controls $(\mathrm{p}<0.05, \mathrm{p}<0.01$ and $\mathrm{p}<$ 0.001 ); however, 12.5 and $25 . \mu \mathrm{g} / \mathrm{ml}$ of t-BHP had no significant effect on fibroblast cell viability (Fig. 1B) ( $\mathrm{p} \geq 0.05)$.

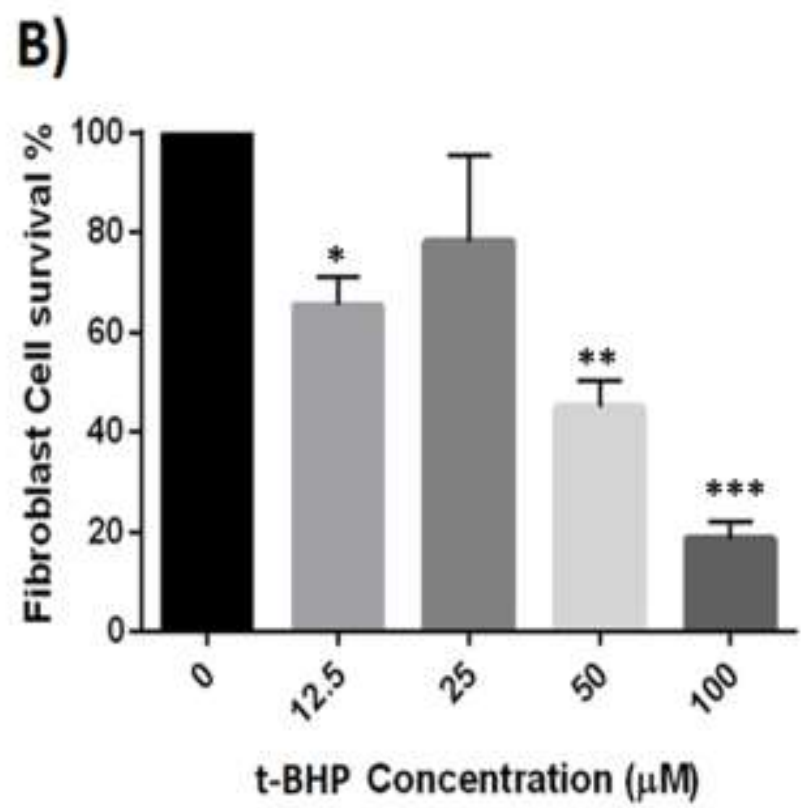

Fig. 1. A) MCF-7 cell and B) fibroblast survival percentages after $1 \mathrm{~h}$ of t-BHP treatment $(0,12.5,25,50$ and $100 \mu \mathrm{M})$ in culture medium. Cell survival was determined by MTT assay. All results were shown mean \pm SD of three separated experiments. ${ }^{*} \mathrm{p}<0.05$, ${ }^{* *} \mathrm{p}<0.01$ and ${ }^{* * *} \mathrm{p}<0.001$ compared with the untreated control group. 
Effect of Thymol on MCF-7 and fibroblast cell survival

The toxicity of increasing thymol concentrations on MCF-7 and fibroblast cell survival after $24 \mathrm{~h}$ was also determined by MTT assay. Thymol $(50-800 \mu \mathrm{g} / \mathrm{ml})$ significantly inhibited MCF-7 cell viability at all

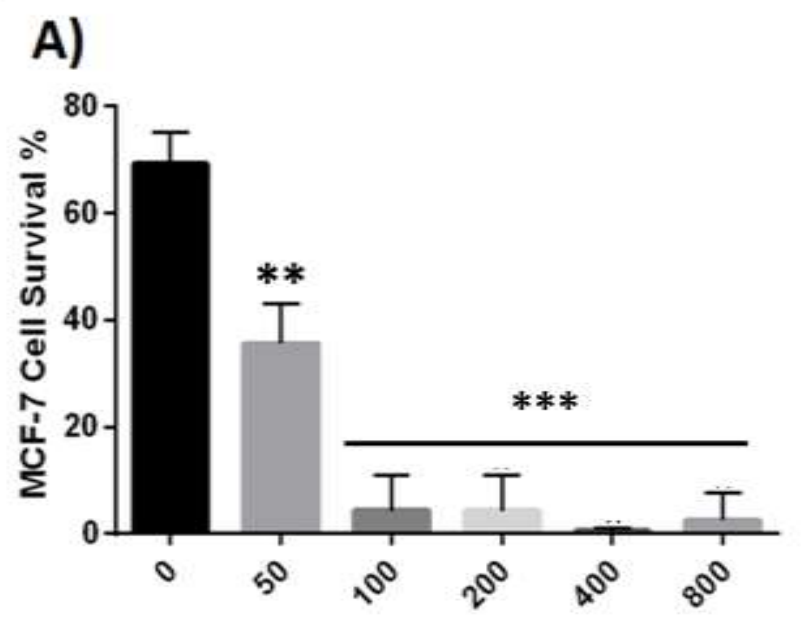

Thymol Concentration $\left(\mu_{\mathrm{g}} / \mathrm{ml}\right)$ concentrations (Fig. 2A) ( $\mathrm{p}<0.01$ and $\mathrm{p}<$ $0.001)$. In contrast, thymol had no apparent toxic effect on fibroblasts at 50 or $100 \mu \mathrm{g} / \mathrm{ml}$; however, at 200, 400, and $800 \mu \mathrm{g} / \mathrm{ml}$ it significantly inhibited cell viability (Fig. 2B) $(p<0.01$ and $p<0.001)$.

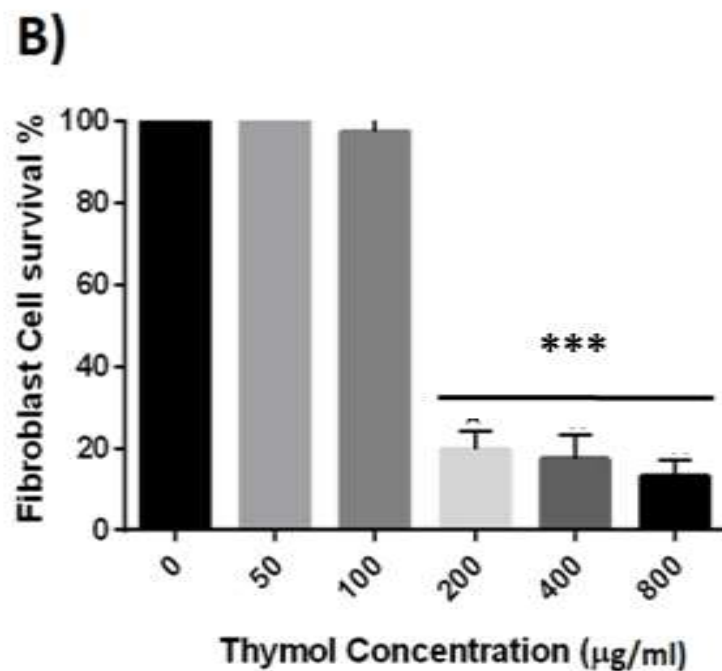

Fig. 2. A) MCF-7 cell and B) Fibroblast survival percentages after $24 \mathrm{~h}$ of thymol treatment $(0,50,100,200,400 \mathrm{and} 800 \mu \mathrm{g} / \mathrm{ml}) \mathrm{in}$ the culture medium. Cell survival was determined by MTT assay. Data was shown mean \pm SD of three independent experiments. ${ }^{*} \mathrm{p}<$ $0.05,{ }^{* *} \mathrm{p}<0.01$ and ${ }^{* * *} \mathrm{p}<0.001$ compared with the untreated control group.

The effect of thymol pre-treatment on MCF-7 cell and fibroblast viability

In the pre-treatment group, the cells were exposed to increasing thymol concentrations for $24 \mathrm{~h}, 50 \mu \mathrm{M}$ t-BHP was added for one hour, and MTT assays were performed. MCF-7 cell viability in the thymol pre-treatment groups $(50-800 \mu \mathrm{g} / \mathrm{ml})$ was significantly less than in the untreated group $(\mathrm{p}<0.05, \mathrm{p}<0.01$ and $\mathrm{p}<$ 0.001) (Fig. 3A). When MCF-7 cells were preincubated with different concentrations of Thymol $(50-800 \mu \mathrm{g} / \mathrm{ml})$ in the presence of 50 $\mu \mathrm{M}$ of $\mathrm{t}-\mathrm{BHP}$ for one $\mathrm{h}$, the cell viability significantly decreased compared to the untreated group $(p<0.01$ and $p<0.001)$

(Fig. 3A). Interestingly, the addition of 50 $\mu \mathrm{g} / \mathrm{ml}$ of Thymol in the presence of $50 \mu \mathrm{M}$ of $\mathrm{t}$ BHP reduces the oxidative effect of t-BHP compared to the t-BHP group alone, but it was not statistically significant ( $\mathrm{p} \geq 0.05$ ).

Fibroblast cell viability in the pre-treatment with Thymol at $200-800 \mu \mathrm{g} / \mathrm{ml}$ was significantly less than the untreated group $(\mathrm{p}<$
0.001) Fibroblast cell viability in the pretreatment group showed that $50 \mu \mathrm{g} / \mathrm{ml}$ of Thymol in the presence of $50 \mu \mathrm{M}$ of t-BHP increased the cell viability compared to t-BHP. However, it was not statistically significant $(\mathrm{p} \geq$ 0.05) (Fig. 3B).

\section{The effect of thymol post-treatment on MCF-7 and fibroblast cell survival}

The cells were treated for one h with $50 \mu \mathrm{M}$ tBHP, then incubated with increasing doses of Thymol $(50-800 \mu \mathrm{g} / \mathrm{ml})$ for $24 \mathrm{~h}$, and the MTT assay was performed. The viabilities of both cell types were significantly less than controls when treated with 200,400 , or $800 \mu \mathrm{g} / \mathrm{ml}$ of Thymol $(p<0.001)$, while viabilities of cells treated with $50 \mu \mathrm{g} / \mathrm{ml}$ of Thymol were not significantly different from controls $(\mathrm{p} \geq 0.05)$ (Fig. 4).

\section{FRAP index in cell culture medium}

After pre- and post-treatment with Thymol (0$800 \mu \mathrm{g} / \mathrm{ml}$ ), the FRAP test was performed on the collected supernatants when MCF-7 cells 
were pre-treated with 200 and $400 \mu \mathrm{g} / \mathrm{ml}$ of Thymol $(24 \mathrm{~h})$ in the presence of $50 \mu \mathrm{M}$ of tBHP, the FRAP index was significantly less than the non-treated control $(\mathrm{p}<0.05)$. In fibroblasts treated with $400 \mathrm{ug} / \mathrm{ml}$ of Thymol $(24 \mathrm{~h})$, the FRAP level was significantly less than the untreated control group $(\mathrm{p}<0.05)$.
In the post-treatment, no significant differences were observed in MCF-7 cells (Table 1) ( $\mathrm{p} \geq$ 0.05 ), while the FRAP indexes in the fibroblast cells treated with 100, 200, 400, and $800 \mu \mathrm{g} / \mathrm{ml}$ of Thymol were significantly more significant than the controls $(\mathrm{p}<0.05)$ (Table 1).

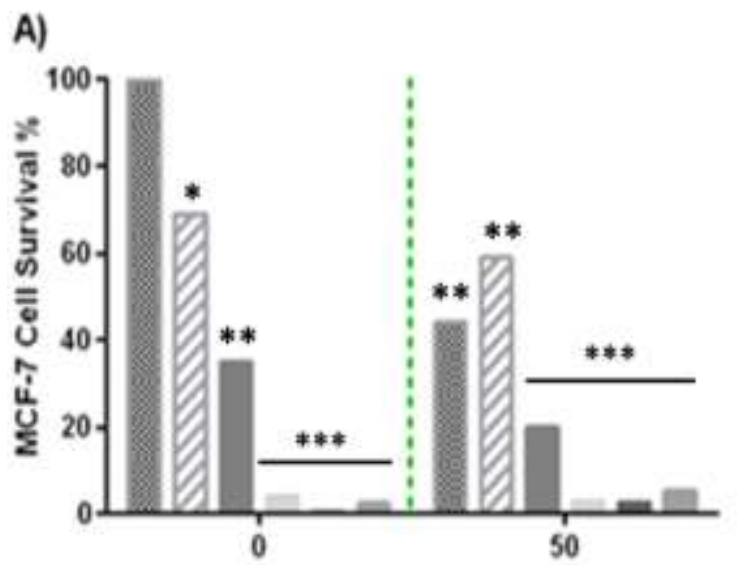

Thymol pre-treatment $(\mu \mathrm{g} / \mathrm{ml})+\mathrm{t}-\mathrm{BHP}(\mu \mathrm{M})$
B)

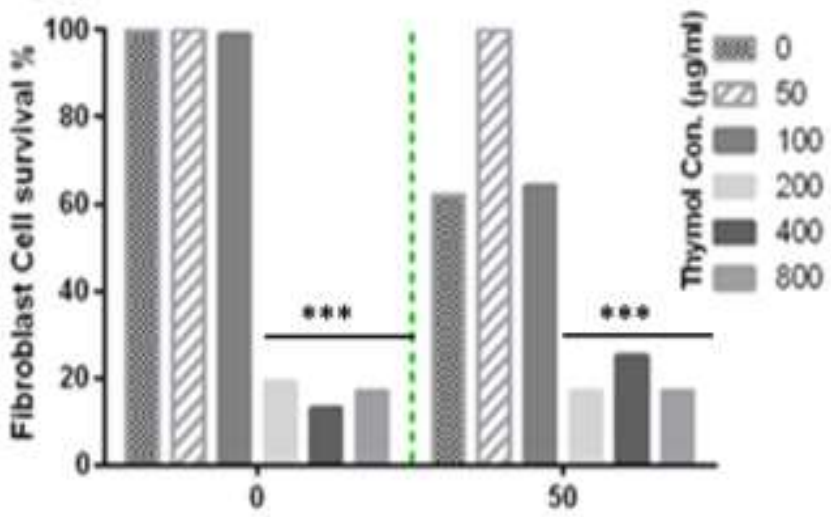

Thymol pre-treatment $(\mu \mathrm{g} / \mathrm{ml})+\mathrm{t}-\mathrm{BHP}(\mu \mathrm{M})$

Fig. 3. A) MCF-7 cell and B) Fibroblast survival percentages after 24 h of pre-treatment with Thymol (0, 50, 100, 200, 400 and $800 \mu \mathrm{g} / \mathrm{ml}$ ) and then one h of incubation with $50 \mu \mathrm{M} \mathrm{t}-\mathrm{BHP}$ in the culture medium. Cell survival was determined by MTT assay. All results were shown mean $\pm \mathrm{SD}$ of three separated experiments. ${ }^{*} \mathrm{p}<0.05,{ }^{* *} \mathrm{p}<0.01$ and ${ }^{* * *} \mathrm{p}<0.001$ compared with the untreated control group.
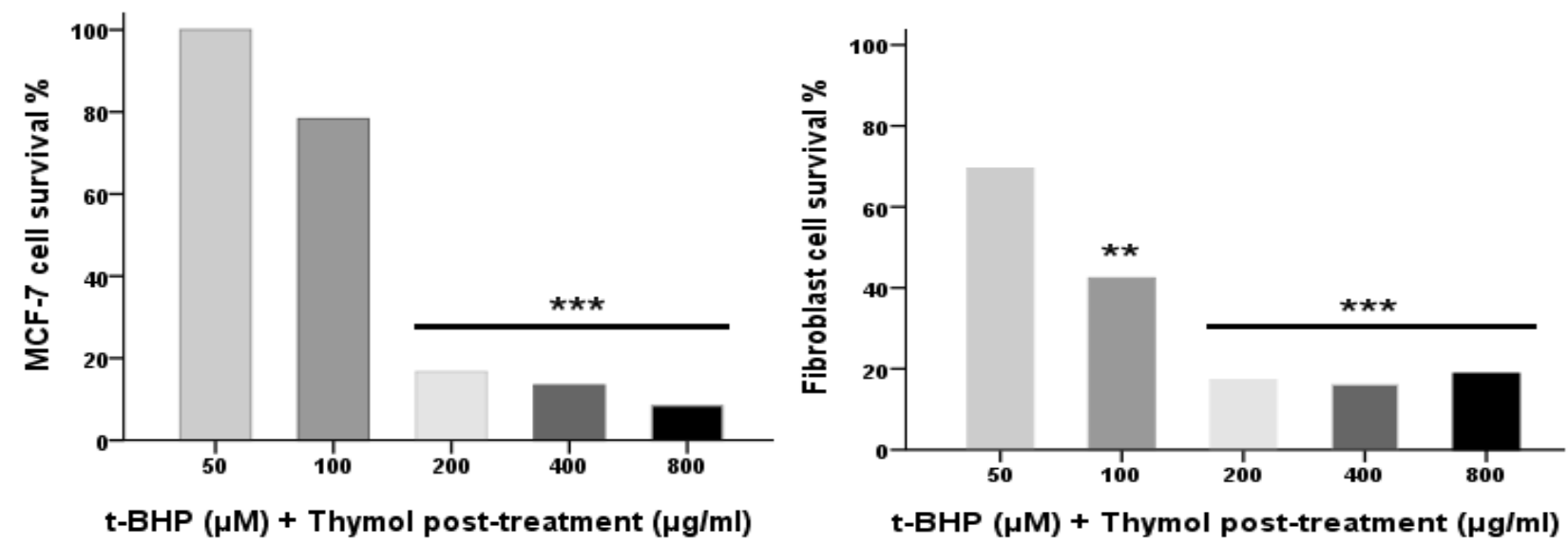

Fig. 4. MCF-7 cell and fibroblast survival percentages after one h of) incubation with $50 \mu \mathrm{M}$ t-BHP and then 24 hours with thymol post-treatment $(0,50,100,200,400$ and $800 \mu \mathrm{g} / \mathrm{ml})$ in culture medium. Cell survival was determined by MTT assay. Data was shown mean \pm SD of three independent experiments. ${ }^{*} \mathrm{p}<0.05,{ }^{* *} \mathrm{p}<0.01$ and ${ }^{* * *} \mathrm{p}<0.001$ compared with the control group. 
Table 1. FRAP values in pre- and post-treatment groups.

\begin{tabular}{|c|c|c|c|c|c|c|c|c|}
\hline Treatment & Cell line & $\begin{array}{l}\text { Thymol } \\
(\mu \mathrm{g} / \mathrm{ml}) \\
\text { t-BHP } \\
(\mu \mathrm{M})\end{array}$ & 0 & 50 & 100 & 200 & 400 & 800 \\
\hline \multirow{4}{*}{$\begin{array}{l}\text { Pre- } \\
\text { treatment }\end{array}$} & \multirow{2}{*}{ MCF-7 } & 0 & $243 \pm 0.01$ & $150 \pm 0.04$ & $155.2 \pm 0.01$ & $137.6 \pm 0.01$ & $182.3 \pm 0.05$ & $208.09 \pm 0.06$ \\
\hline & & 50 & $382.1 \pm 0.03$ & $203.3 \pm 0.03$ & $174.2 \pm 0.01$ & $125.2 * \pm 0.01$ & $125.7^{*} \pm 0.04$ & $135.7 \pm 0.03$ \\
\hline & \multirow{2}{*}{ Fibroblast } & 0 & $205.2 \pm 0.01$ & $180 \pm 0.01$ & $213.3 \pm 0.01$ & $257.6 \pm 0.02$ & $319.5 \pm 0.04$ & $523.8 \pm 0.19$ \\
\hline & & 5 & $353.5 \pm 0.04$ & $166.1 \pm 0.03$ & $175.7 \pm 0.01$ & $150.9 \pm 0.05$ & $123.3^{*} \pm 0.01$ & $131.9 \pm 0.01$ \\
\hline \multirow{4}{*}{$\begin{array}{l}\text { Post- } \\
\text { treatment }\end{array}$} & \multirow{2}{*}{ MCF-7 } & 0 & $240 \pm 0.03$ & $150 \pm 0.04$ & $155.2 \pm 0.01$ & $137.6 \pm 0.01$ & $182.3 \pm 0.05$ & $208 \pm 0.06$ \\
\hline & & 50 & $382.1 \pm 0.03$ & $194.7 \pm 0.008$ & $206.6 \pm 0.05$ & $274.2 \pm 0.03$ & $370.4 \pm 0.09$ & $545.7 \pm 0.1$ \\
\hline & \multirow{2}{*}{ Fibroblast } & 0 & $240 \pm 0.03$ & $180 \pm 0.01$ & $213.3 \pm 0.01$ & $257.6 \pm 0.02$ & $319.5 \pm 0.04$ & $523.8 \pm 0.19$ \\
\hline & & 50 & $353.5 \pm 0.04$ & $232.3 \pm 0.01$ & $340.4 * \pm 0.02$ & $422.3 * * \pm 0.03$ & $683.3^{* *} \pm 0.05$ & $807.1 * * * \pm 0.00$ \\
\hline
\end{tabular}

* In the pre-treatment group, MCF-7 and fibroblast cells were pre-treated with 0, 50, 100, 200, 400, or $800 \mu \mathrm{g} / \mathrm{ml}$ of thymol for $24 \mathrm{~h}$; then t-BHP was added $(0$ or $50 \mu \mathrm{M})$ for $1 \mathrm{~h}$. In the post-treatment group, MCF-7 and fibroblast cells were first incubated with $50 \mu \mathrm{M}$ t-BHP for $1 \mathrm{~h}$, then Thymol was added at $0,50,100,200,400$, or $800 \mu \mathrm{g} / \mathrm{ml}$ for $24 \mathrm{~h}$. After $24 \mathrm{~h}$ incubation, the culture medium was collected for FRAP test by ELISA reader. All results were shown mean \pm SD of three independent experiments. ${ }^{*} \mathrm{p}<0.05,{ }^{* *} \mathrm{p}<0.01$ and ${ }^{* * *} \mathrm{p}<0.001$ compared with the untreated control group.

\section{TBARS Index in cell culture medium}

The TBARS test was also performed on cell supernatants from the pre- and post-treated cells. No significant differences were seen between the thymol pre- and post-treated cells and controls ( $p>0.05)$ (Table2).

\section{DPPH index in cell culture medium}

Pre-treatment of MFC-7 and fibroblast cells with Thymol, either with or without t-BHP, did not affect DPPH indexes, nor did thymol posttreatment of MCF-7 cells. However, fibroblast cells treated first with $50 \mu \mathrm{M}$ t-BHP and then post-treated with Thymol at concentrations of $100 \mu \mathrm{g} / \mathrm{ml}$ and greater showed DPPH values significantly more significant than the untreated and t-BHP control groups $(\mathrm{p}<0.01)($ Table 3$)$.

Table 2. TBARS values in Pre-treatment and Post-treatment groups.

\begin{tabular}{|c|c|c|c|c|c|c|c|c|}
\hline Treatment & Cell line & $\begin{array}{c}\text { Thymol } \\
(\mu \mathrm{g} / \mathrm{ml}) \\
\text { t-BHP } \\
(\mu \mathrm{M})\end{array}$ & $\mathbf{0}$ & 50 & 100 & 200 & 400 & 800 \\
\hline \multirow{4}{*}{ Pre-treatment } & \multirow{2}{*}{ MCF-7 } & 0 & $49.3 \pm 0.05$ & $53.7 \pm 0.03$ & $44.8 \pm 0.01$ & $30.5 \pm 0.03$ & $34.8 \pm 0.03$ & $32.5 \pm 0.02$ \\
\hline & & 50 & $32.8 \pm 0.01$ & $54.03 \pm 0.03$ & $47.7 \pm 0 \ldots .6$ & $36.5 \pm 0.03$ & $34.5 \pm 0.03$ & $32 \pm 0.03$ \\
\hline & \multirow{2}{*}{ Fibroblast } & 0 & $59.2 \pm 0.03$ & $39.7 \pm 0.01$ & $49.7 \pm 0.01$ & $37.5 \pm 0.01$ & $43.5 \pm 0.01$ & $46.8 \pm 0.03$ \\
\hline & & 50 & $57.5 \pm 0.01$ & $79.7 \pm 0.06$ & $79.7 \pm 0.05$ & $86.2 \pm 0.05$ & $79.7 \pm 0.02$ & $69.7 \pm 0.05$ \\
\hline \multirow{4}{*}{ Post-treatment } & \multirow{2}{*}{ MCF-7 } & 0 & $42.9 \pm 0.00$ & $53.7 \pm 0.03$ & $44.8 \pm 0.01$ & $30.5 \pm 0.03$ & $34.8 \pm 0.03$ & $32.5 \pm 0.02$ \\
\hline & & 50 & $32.8 \pm 0.01$ & $31.3 \pm 0.03$ & $30.5 \pm 0.02$ & $24.3 \pm 0.02$ & $28.5 \pm 0.01$ & $24.8 \pm 0.01$ \\
\hline & \multirow{2}{*}{ Fibroblast } & 0 & $59.2 \pm 0.03$ & $39.7 \pm 0.01$ & $49.7 \pm 0.01$ & $37.5 \pm 0.01$ & $43.5 \pm 0.01$ & $46.8 \pm 0.03$ \\
\hline & & 50 & $57.5 \pm 0.01$ & $51.8 \pm 0.01$ & $55.5 \pm 0.00$ & $56.3 \pm 0.01$ & $59.03 \pm 0.01$ & $61.7 \pm 0.07$ \\
\hline
\end{tabular}

*In the pre-treatment group, MCF-7 and fibroblast cells were pre-incubated with thymol $(0,50,100,200,400$, or $800 \mu \mathrm{g} / \mathrm{ml})$ for $24 \mathrm{~h}$; then t-BHP was added $(0$ or $50 \mu \mathrm{M})$ for $1 \mathrm{~h}$. In the post-treatment group, MCF-7 and fibroblast cells were first exposed with $50 \mu \mathrm{M}$ t-BHP for $1 \mathrm{~h}$, then Thymol $(0,50,100,200,400$, or $800 \mu \mathrm{g} / \mathrm{ml})$ was added for $24 \mathrm{~h}$. After $24 \mathrm{~h}$ incubation, the culture medium was collected for TBARS assay by ELISA reader. All results were shown mean \pm SD of three separated experiments. 
Table 3. DPPH values in Pre-treatment and Post-treatment groups.

\begin{tabular}{|c|c|c|c|c|c|c|c|c|}
\hline Treatment & Cell line & $\begin{array}{c}\text { Thymol } \\
(\mu \mathrm{g} / \mathrm{ml}) \\
\text { t-BHP } \\
(\mu \mathrm{M})\end{array}$ & 0 & 50 & 100 & 200 & 400 & 800 \\
\hline \multirow{4}{*}{$\begin{array}{c}\text { Pre- } \\
\text { treatment }\end{array}$} & \multirow{2}{*}{ MCF-7 } & 0 & $17.64 \pm 0.02$ & $17.23 \pm 0.08$ & $15.75 \pm 0.03$ & $15.53 \pm 0.04$ & $16.27 \pm 0.01$ & $20.76 \pm 0.1$ \\
\hline & & 50 & $15.81 \pm 0.09$ & $17.74 \pm 0.07$ & $17.04 \pm 0.10$ & $17.78 \pm 0.17$ & $16.84 \pm 0.04$ & $19.38 \pm 0.09$ \\
\hline & \multirow{2}{*}{ Fibroblast } & 0 & $17.8 \pm 0.04$ & $15.75 \pm 0.06$ & $17.7 \pm 0.04$ & $16.57 \pm 0.03$ & $17.1 \pm 0.04$ & $16.50 \pm 0.03$ \\
\hline & & 50 & $16.1 \pm 0.04$ & $17 \pm 0.02$ & $18.1 \pm 0.05$ & $17.47 \pm 0.07$ & $17.68 \pm 0.03$ & $17.89 \pm 0.08$ \\
\hline \multirow{4}{*}{$\begin{array}{c}\text { Post- } \\
\text { treatment }\end{array}$} & \multirow{2}{*}{ MCF-7 } & 0 & $16.12 \pm 0.1$ & $17.23 \pm 0.08$ & $15.75 \pm 0.03$ & $15.53 \pm 0.04$ & $16.27 \pm 0.01$ & $20.76 \pm 0.1$ \\
\hline & & 50 & $15.81 \pm 0.09$ & $15.89 \pm 0.09$ & $15.01 \pm 0.08$ & $14.97 \pm 0.04$ & $15.02 \pm 0.03$ & $14.53 \pm 0.05$ \\
\hline & \multirow[b]{2}{*}{ Fibroblast } & 0 & $15.81 \pm 0.05$ & $15.75 \pm 0.06$ & $17.7 \pm 0.04$ & $16.57 \pm 0.03$ & $17.1 \pm 0.04$ & $16.5 \pm 0.03$ \\
\hline & & 50 & $16.15 \pm 0.04$ & $17.9 \pm 0.06$ & $\begin{array}{c}55.5 \pm 0.00 * \\
* / \# \#\end{array}$ & $\begin{array}{c}56.3 \pm 0.01 \text { **/\# } \\
\#\end{array}$ & $\begin{array}{c}59.03 \pm 0.01 \\
* * / \# \#\end{array}$ & $\begin{array}{c}61.7 \pm 0.07 * * / \\
\ldots \#\end{array}$ \\
\hline
\end{tabular}

*In the pre-treatment group, MCF-7 and fibroblast cells were first exposed with thymol $(0,50,100,200,400$, or $800 \mu \mathrm{g} / \mathrm{ml})$ for $24 \mathrm{~h}$; then t-BHP was added $(0$ or $50 \mu \mathrm{M})$ for $1 \mathrm{~h}$. In the post-treatment group, MCF-7 and fibroblast cells were first exposed with $50 \mu \mathrm{M}$ t-BHP for $1 \mathrm{~h}$, then Thymol $(0,50,100,200,400$, or $800 \mu \mathrm{g} / \mathrm{ml})$ was added for $24 \mathrm{~h}$. After $24 \mathrm{~h}$ incubation, the culture medium was collected for DPPH assay using a spectrophotometer at $517 \mathrm{~nm} .{ }^{* *} \mathrm{p}<0.01$ compared with the untreated control group. ${ }^{\#} \mathrm{p}<0.01$ compared with the t-BHP control group.

\section{Discussion}

In this manuscript, we reported that pre-and posttreatment of MCF-7 and fibroblast cells with Thymol accompanied by t-BHP had significantly more cytotoxicity compared with both untreated and t-BHP groups in a dose-dependent manner.

Many studies have recently been done on the protective effects of natural antioxidants against oxidative stress in both in vitro and in vivo (1921). However, several studies have shown that some antioxidants can act as a pro-oxidant under certain conditions, increasing ROS production, and resulting in cell damage $(22,23)$. The oxidation effects of these antioxidant compounds may vary depending on their dosage, exposure time, and intracellular interference (24). Among the known antioxidants, Thymol, a monocyclic monoterpene, has shown various biological activities, including antioxidant, antiinflammatory, and anti-microbial anti-diabetic, and neuropharmacological effects $(12,13)$. In vitro studies have shown that thymol treatment suppressed oxidant-induced DNA damage, cell cycle arrest, and apoptosis in different cancer cells. These reports revealed that Thymol is a potent anti-tumor agent (26-28). However, there is no study on Thymol's effect on cytotoxicity and oxidative stress in MCF-7 cells and foreskin fibroblasts. Based on previous research, t-BHP, as an acute oxidant, was used to evaluate the antioxidant and anti-proliferation activity of Thymol in cellular models (16). Here, we used increasing concentrations of Thymol to investigate its effects on MCF-7 and fibroblast cells in the presence and absence of t-BHP. Thymol significantly reduced cell viability of MCF-7 cancer cells at all concentrations tested. In the normal fibroblasts, thymol only at concentrations of $200 \mu \mathrm{g} / \mathrm{ml}$ and above led to cell viability reduction. Accordingly, Thymol appears to be more toxic to MCF-7 than fibroblast cells after 24 hours of incubation. Also, pre- and posttreatment with Thymol in the presence of t-BHP significantly reduced the MCF-7 cell and fibroblast viability compared to controls in a dosedependent manner. Therefore, thymol pretreatment seems to be more effective than posttreatment for cell survival.

Thymol has free radical scavenging activity to reduce oxidative stress $(29,30)$. A study using Chang cells at $12.5,25$, and $50 \mu \mathrm{g} / \mathrm{ml}$ of Thymol and $80 \mu \mathrm{M}$ t-BHP showed that Thymol increased cell survival. Thymol protects Chang cells against oxidative stress by preventing mitochondrial membrane potential (MMP) loss and inhibiting overproduction of ROS and lipid peroxidation (MDA levels) resulting from oxidative stress (16). 
Here, we used different cell lines and different doses of Thymol $(50 \mu \mathrm{g} / \mathrm{ml}$ and higher) and tBHP $(50 \mu \mathrm{M})$. Pre- and post-treatment with Thymol and t-BHP showed no significant differences in MDA levels in the MCF-7 and fibroblast cells. Compared to Chang cells, our different results could be due to differences in Thymol doses and the type of cells. At high concentrations, it appears Thymol may have been unable to protect the cells from the oxidative damage caused by t-BHP.

A study that examined the protective effects of Thymol on lipid peroxidation and nonenzymatic antioxidants in isoproterenol-induced myocardial infarction in rats reported that Thymol could trap and regenerate the superoxide anion, hydroxyl, in a dose-dependent manner (31). In 2016, Palabiyik et al. examined the protective effect of Thymol on HepG2 cells.

They reported that Thymol at concentrations of $25,50,100 \mu \mathrm{M}$ reduced oxidative damage and improved the antioxidant enzyme activity after 24, 48, and $72 \mathrm{~h}$. At higher concentrations, this phenolic compound may oxidize and release free radicals $(32,33)$. Thymol $(10-400 \mu \mathrm{M})$ had cytotoxic, genotoxic, and apoptotic effects on

\section{References}

1. Rojas K, Stuckey A. Breast cancer epidemiology and risk factors. Clin Obstet Gynecol. 2016;59(4):651-672.

2. Bray F, Ferlay J, Soerjomataram I, Siegel RL, Torre LA, Jemal A. Global cancer statistics 2018: GLOBOCAN estimates of incidence and mortality worldwide for 36 cancers in 185 countries. CA Cancer J Clin. 2018;68(6):394-424.

3. Nourazarian AR, Kangari P, Salmaninejad A. Roles of oxidative stress in the development and progression of breast cancer. Asian Pac J Cancer Prev. 2014;15(12):4745-51.

4. Gupta RK, Patel AK, Kumari R, Chugh S, Shrivastav C, Mehra S, et al. Interactions between oxidative stress, lipid profile and antioxidants in breast cancer: a case control study. Asian Pac J Cancer Prev. 2012;13(12):6295-8.

5. Vieira FGK, Pietro PFD, Boaventura BCB, Ambrosi C, Rockenbach G, Fausto MA, et al.
AGS gastric cancer cells by producing ROS and reducing glutathione (34). In another report, Thymol at $400 \mathrm{mg} / \mathrm{L}$ was shown to exhibit antiproliferation effects, whereas at 19,25 , and 50 $\mathrm{mg} / \mathrm{L}$ after thymol treatment, the total antioxidant capacity was increased in cultured neuroblastoma cells ( $\mathrm{N} 2 \mathrm{a}$ cells) (25).

In our study, with increasing concentration in pre-treatment with Thymol, no significant change was observed in Thymol's free-radical scavenging activity in both cell lines. This can be attributed to the presence of t-BHP as an oxidant. In post-treatment with Thymol, free-radical scavenging activity increased in fibroblast cells compared to MCF-7 cell line. We also observed that pre- and post-treatment with Thymol in the presence of t-BHP affected the total antioxidant capacity in both MCF-7 and fibroblast cells.

\section{Acknowledgements}

This study (No. 9604973) was supported by the Babol University of Medical Sciences, I.R. Iran. Financial support from the Babol University of Medical Sciences is acknowledged.

The authors declare that there is no conflict of interest.

Factors associated with oxidative stress in women with breast cancer. 2011.

6. Abazari O, Shafaei Z, Divsalar A, EslamiMoghadam M, Ghalandari B, Saboury AA. Probing the biological evaluations of a new designed $\mathrm{Pt}$ (II) complex using spectroscopic and theoretical approaches: Human hemoglobin as a target. J Biomol Struct Dyn. 2016;34(5):1123-31.

7. Seresht HR, Albadry BJ, Al-mosawi AKM, Gholami O, Cheshomi $\mathrm{H}$. The cytotoxic effects of Thymol as the major component of trachyspermum ammi on breast cancer (MCF-7) cells. Pharmaceutical Chemistry Journal. 2019;53(2):101-107.

8. Deb DD, Parimala G, Devi SS, Chakraborty T. Effect of Thymol on peripheral blood mononuclear cell PBMC and acute promyelotic cancer cell line HL-60. Chem Biol Interact. 2011;193(1):97-106.

9. Islam MT, Khalipha AB, Bagchi R, Mondal M, Smrity SZ, Uddin SJ, et al. Anticancer activity of 
Thymol: A literature-based review and docking study with Emphasis on its anticancer mechanisms. IUBMB life. 2019;71(1):9-19.

10. Elbe H, Yigitturk G, Cavusoglu T, Uyanikgil Y, Ozturk F. Apoptotic effects of Thymol, a novel monoterpene phenol, on different types of cancer. Bratisl Lek Listy. 2020;121(2):122-128.

11. Abazari O, Divsalar A, Ghobadi R. Inhibitory effects of oxali-Platin as a chemotherapeutic drug on the function and structure of bovine liver catalase. $\mathrm{J}$ Biomol Struct Dyn. 2020;38(2):609-615.

12. Meeran MFN, Javed H, Al Taee H, Azimullah S, Ojha SK. Pharmacological properties and molecular mechanisms of Thymol: prospects for its therapeutic potential and pharmaceutical development. Front pharmacol. 2017;8:380.

13. Li X, He T, Wang X, Shen M, Yan X, Fan S, et al. Traditional uses, chemical constituents and biological activities of plants from the genus Thymus. Chem Biodivers. 2019;16(9):e1900254.

14. Nabavi SM, Marchese A, Izadi M, Curti V, Daglia M, Nabavi SF. Plants belonging to the genus Thymus as antibacterial agents: From farm to pharmacy. Food chem. 2015;173:339-47.

15. Asadi A, Nezhad DY, Javazm AR, Khanicheragh P, Mashouri L, Shakeri F, et al. In vitro Effects of Curcumin on Transforming Growth Factor- $\beta$-mediated Non-Smad Signaling Pathway, Oxidative Stress, and Pro-inflammatory Cytokines Production with Human Vascular Smooth Muscle Cells. Iranian J Allergy Asthma and Immunol. 2019;19(1):84-93.

16. Kim Y-S, Hwang J-W, Kang S-H, Kim E-H, Jeon Y-J, Jeong J-H, et al. Thymol from Thymus quinquecostatus Celak. protects against tert-butyl hydroperoxide-induced oxidative stress in Chang cells. J Nat Med. 2014;68(1):154-62.

17. Mosmann T. Rapid colorimetric assay for cellular growth and survival: application to proliferation and cytotoxicity assays. J Immunol Methods. 1983;65(1-2):55-63.

18. Niehaus Jr W, Samuelsson B. Formation of malonaldehyde from phospholipid arachidonate during microsomal lipid peroxidation. Eur $\mathbf{J}$ Biochem. 1968;6(1):126-30.

19. Adewoyin M, Ibrahim M, Roszaman R, Isa MLM, Alewi NAM, Rafa AAA, et al. Male infertility: the effect of natural antioxidants and phytocompounds on seminal oxidative stress. Diseases. 2017;5(1):9.

20. Ceriello A, Testa R, Genovese S. Clinical implications of oxidative stress and potential role of natural antioxidants in diabetic vascular complications. Nutr Metab Cardiovasc Dis. 2016;26(4):285-92.

21. Abazari O, Shafaei Z, Divsalar A, EslamiMoghadam M, Ghalandari B, Saboury AA, et al. Interaction of the synthesized anticancer compound of the methyl-glycine 1,10-phenanthroline platinum nitrate with human serum albumin and human hemoglobin proteins by spectroscopy methods and molecular docking. Journal of the Iranian Chemical Society. 2020:1601-1614.

22. Wang X, Wu Q, Liu A, Anadón A, Rodríguez JL, Martínez-Larrañaga M-R, et al. Paracetamol: overdose-induced oxidative stress toxicity, metabolism, and protective effects of in vivo various compounds and in vitro. Drug Metab Rev. 2017;49(4):395-437.

23. Wang N, Yi WJ, Tan L, Zhang JH, Xu J, Chen $\mathrm{Y}$, et al. Apigenin attenuates streptozotocin-induced pancreatic $\beta$ cell damage by its protective effects on cellular antioxidant defense. In Vitro Cell Dev Biol Anim. 2017;53(6):554-563.

24. Olson KR, Gao Y. Effects of inhibiting antioxidant pathways on cellular hydrogen sulfide and polysulfide metabolism. Free Radic Biol Med. 2019;135:1-14.

25. Aydın E, Turkez H, Tasdemir S, Hacımuftuoglu F. Anticancer, antioxidant and cytotoxic potential of Thymol in vitro brain tumor cell model. Cent Nerv Syst Agents in Med Chem. 2017;17(2):116-122.

26. Li Y, Wen J-m, Du C-j, Hu S-m, Chen J-X, Zhang S-g, et al. Thymol inhibits bladder cancer cell proliferation via inducing cell cycle arrest and apoptosis. Biochem Biophys Res Commun. 2017;491(2):530-536.

27. Jamali T, Kavoosi G, Safavi M, Ardestani SK. In-vitro evaluation of apoptotic effect of OEO and Thymol in 2D and 3D cell cultures and the study of their interaction mode with DNA. Sci Rep. 2018;8(1):15787.

28. Abbasi M, Abazari OO. Probing the Biological evaluations of a new designed Palladium (II) complex using spectroscopic and theoretical approaches: Human Hemoglobin as a Target. 
Archives of Medical Laboratory Sciences. 2018;3(3).

29. Zheng C, An X, Yin T. New metal-free catalytic degradation systems with carbon dots for thymol blue. New Journal of Chemistry. 2017;41(22):13365-9.

30. Qazi MA, Molvi KI. Free radicals and their management. American Journal of Pharmacy and Health Research. 2018;6(4):1-10.

31. Jafari A, Rasmi Y, Hajaghazadeh M, Karimipour M. Hepatoprotective effect of Thymol against subchronic toxicity of titanium dioxide nanoparticles: Biochemical and histological evidences. Environmental Toxicology and Pharmacology. 2018;58:29-36.

32. Palabiyik S, Karakus E, Halici Z, Cadirci E, Bayir Y, Ayaz G, et al. The protective effects of carvacrol and Thymol against paracetamol-induced

toxicity on human hepatocellular carcinoma cell lines (HepG2). Hum Exp Toxicol. 2016;35(12):1252-1263.

33. Kang S-H, Kim Y-S, Kim E-K, Hwang J-W, Jeong $\mathrm{J}-\mathrm{H}$, Dong $\mathrm{X}$, et al. Anticancer effect of Thymol on AGS human gastric carcinoma cells. J Microbiol Biotechnol. 2016;26(1):28-37.

34. Günes-Bayir A, Kocyigit A, Kiziltan HS. Effects of Thymol, a natural phenolic compound, on human gastric adenocarcinoma cells In vitro. Alternative therapies in health and medicine. 2019;25(2):12-21.

35. Llana-Ruiz-Cabello M, Gutiérrez-Praena D, Pichardo S, Moreno FJ, Bermúdez JM, Aucejo S, et al. Cytotoxicity and morphological effects induced by carvacrol and thymol on the human cell line Caco-2. Food and Chemical Toxicology. 2014;64:281-290. 